\title{
Assessment of Air Pollution, by the Urban Traffic, in University Campus of Bucharest
}

\author{
Razvan Ştefan Popescu, Lelia Letitia Popescu* \\ Technical University of Civil Engineering of Bucharest, Bucharest, Romania \\ Email: ${ }^{\star}$ lelialetitia@yahoo.com
}

How to cite this paper: Popescu, R.Ş. and Popescu, L.L. (2017) Assessment of Air Pollution, by the Urban Traffic, in University Campus of Bucharest. Journal of Environmental Protection, 8, 884-897. https://doi.org/10.4236/jep.2017.88055

Received: June 28, 2017

Accepted: July 15, 2017

Published: July 18, 2017

Copyright $\odot 2017$ by authors and Scientific Research Publishing Inc. This work is licensed under the Creative Commons Attribution International License (CC BY 4.0).

http://creativecommons.org/licenses/by/4.0/

\begin{abstract}
This study aims to measure traffic-related air pollution of vehicles with internal combustion, the main source of emissions of BTEX, organic compounds and $\mathrm{NO}_{x}, \mathrm{NO}_{2}, \mathrm{NO}, \mathrm{O}_{3}, \mathrm{CO}, \mathrm{SO}_{2}, \mathrm{PM}_{10}$ and $\mathrm{PM}_{2.5}$, inorganic compounds, in three sites of the University campus, surrounded by residential areas. According to the University data, around 8000 students are being exposed daily to the measured level of pollution, in all 3 studied places of campus. A mobile laboratory was used, which continuously measures above mentioned pollutants and meteorological parameters. The diurnal variation of BTEX, in a sunny and rainy day showed two peaks of BTEX concentration in the morning and evening. In the rainy days, the non-polar (hydrophobic) compounds as BTEX are mechanically trained by rain into the ground, where either they enter into the groundwater, or volatilized and re-enter in the air. Particulate matter such as $\mathrm{PM}_{10}$ and $\mathrm{PM}_{2.5}$ is, in a large part, carried by the rain into the soil. The polar compounds (hydrophilic, $\mathrm{NO}_{x}, \mathrm{SO}_{2}$ ) dissolves in the rainwater and are absorbed in the soil (increasing soil acidity) and evaporated towards the clouds (leading to acid rain). In our study, BTEX compounds removed by the rain varied between $62 \%-75 \%, \mathrm{NO}_{\mathrm{x}}$ and $\mathrm{SO}_{2}, 80 \%$ and $77 \%$ respectively. Particulate matters were washed out up to $68 \%$ for $\mathrm{PM}_{10}$, and $42 \%$ for $\mathrm{PM}_{2.5}$. In the sunny days the air pollution with measured concentrations of $\mathrm{O}_{3}$ $\left(121.66 \pm 7.02,123.56 \pm 4.89 \mu \mathrm{g} / \mathrm{m}^{3}\right)$ remained for 7 hours close to the limit value $\left(120 \mu \mathrm{g} / \mathrm{m}^{3}\right)$. The maximum of solar radiation, with corresponding low concentrations in $\mathrm{NO}_{\mathrm{x}}$ and xylene, corresponds to photochemical reactions in the atmosphere, generating photochemical smog. In a sunny day and high traffic, we found the maximum value $5.4 \mu \mathrm{g} / \mathrm{m}^{3}$ for benzene, for $30 \mathrm{~min}$., a known human carcinogen, exceeding the annual limit value de $5 \mu \mathrm{g} / \mathrm{m}^{3}$. The average background, from benzene, in three University campuses daily visited by around 8000 students was $0.97 \mu \mathrm{g} / \mathrm{m}^{3}$, exposed to $1.46 \mu \mathrm{g} / \mathrm{m}^{3}$ and the cancer risk is $1 / 100,000$.
\end{abstract}




\section{Keywords}

University Campus Outdoor Air Quality, BTEX, Mobile Laboratory, PM10, PM2.5

\section{Introduction}

Transport related emissions, deforestation, agriculture and fertilizer used and recurrent forest burning are some of the factors that have increased atmospheric pollutant emissions [1]. The fast growth in vehicular traffic means that air pollution might continue to rise in the future.

Vehicles with gasoline and diesel engines emit a wide variety of air pollutants, such as: $\mathrm{CO}, \mathrm{NO}_{2}, \mathrm{SO}_{2}$, volatile organic compounds (VOCs), polycyclic aromatic hydrocarbons (PAHs) and particulate matter (PM) [2].

Volatile organic compounds (VOCs) significantly contribute to the photochemical reactions in the atmosphere. Their reaction with $\mathrm{NO}_{\mathrm{x}}$ in the presence of sunlight generates secondary pollutants and photochemical smog such as $\mathrm{OH}$ radical and ozone [3] [4]. VOCs contribute to $\mathrm{O}_{3}$ formation through a series of photochemical reactions, including the hydroxyl radical $(\mathrm{OH})$ initiated oxidation of VOCs, nitrogen cycling driven by peroxyl $\left(\mathrm{RO}_{2}\right)$ and hydroperoxyl $\left(\mathrm{HO}_{2}\right)$ oxidation and photolysis, and the combination of oxygen atom $(\mathrm{O})$ with molecular oxygen $\left(\mathrm{O}_{2}\right)$ [5] [6]. VOCs are important ozone precursors that contribute to the formation of photochemical smog and secondary organic aerosols.

74 VOC species were detected from the tested vehicles, including 22 alkanes, 6 alkenes, 1 alkynes, 16 aromatics, 3 cyclanes, 10 halohydrocarbons, 12 carbonyls and 4 other compounds [7].

The BTEX (benzene, toluene, ethylbenzene, $\mathrm{m}, \mathrm{p}$-xylene and o xylenes) ratios in total VOCs identified were: $60 \%$ in Hong Kong [8], 70\% of the ambient VOCs in summer in Beijing [9], 33\% in Dinghu Mountain and Beijing [7] [10] etc.

The percentage of BTEX (by weight) in gasoline is $18 \%$ compared to the others and the components, in BTEX, of benzene, toluene, ethylbenzene, m, p-xylene and o xylenes are $11 \%, 26 \%, 11 \%, 40 \%$ and $12 \%$, respectively [11]. Volatilities as benzene and toluene are close to that ratio $\mathrm{B} / \mathrm{T}$, in emissions, of $1 / 2$.

Comparing the lifetime of toluene and benzene in air it was estimated at 2 and 12.5 days, respectively, while xylenes were only $7.8 \mathrm{~h}$ [12]. The photo-oxidation reactions in the air occur at different rates: benzene reacts more slowly with $\mathrm{OH}$ radicals, while toluene/m-xylene reacts 5 times and 19 times as fast as benzene, respectively [13].

The photolysis of BTEX to radicals $\mathrm{OH}$ and $\mathrm{NO}_{3}$ is important in summer, due to the high level of available temperature and solar radiation. This may be the reason why the BTEX values were lower in the summer than in the rainy season [14]. Since BTEX has low solubility and it will not be incorporated into clouds or rain, wet deposition might not affect their depletion. This might result in almost no difference between their concentrations in rainy and summer seasons, as 
observed in some studies [15].

Benzene is a known toxic carcinogen [16] [17] and epigenetic modifications were related to benzene low dose exposures [18]. Toluene is less toxic and causes drowsiness, impaired co-ordination, and liver and kidney damage [19]. Usually, many pollutants coexist in the ambient air, several of which may have additive or even synergistic effects; both benzene and toluene can affect the central nervous system and they usually coexist with each other in the air due to several common resources [2].

The traffic-generated emissions were estimated to account for more than 50\% of the total emissions of particulate matter $\left(\mathrm{PM}_{10}\right.$ and $\left.\mathrm{PM}_{2.5}\right)$, in the urban areas, in highly industrialized countries [20]; in London more than $80 \%$ of particulate matter results from road traffic [2].

If indoor air pollution can be reduced by treatment of incoming fresh air intake, for example, by adsorption on activated carbon filters [21] [22], urban outdoor air pollution can be reduced only by normative measures and the coordination of road traffic.

It was demonstrated that exposure to BTEX was very high for the students living in the urban traffic site [23].

In this paper we assess the traffic-related air pollution, in three different areas of the University campus (noted PP-66 Pache Protopopescu, TE-122-124 Lacul Tei and PL-59 Plevnei), using a mobile laboratory which continuously measures chemical parameters (BTEX, $\mathrm{O}_{3}, \mathrm{NO}_{\mathrm{x}}, \mathrm{NO}, \mathrm{NO}_{2}, \mathrm{CO}, \mathrm{SO}_{2}, \mathrm{PM}_{10}$ and $\mathrm{PM}_{2.5}$ ) and meteorological parameters. The three places of the campus (different locations in Bucharest) are near urban traffic and are surrounded by residential areas. The outcomes shall give indications to the local government in order to implement measures to improve outdoor air quality and decrease human health risks.

\section{Materials and Methods}

The traffic policemen and drivers are much more exposed to traffic-related air pollutants, but it's difficult to measure their exposure using large-scale costsaving methods, since stationary monitoring is not feasible for these highly mobile groups [2].

The analytical procedure usually adopted for the determination of BTEX compounds in urban air used a pre-concentrated probe by active or passive sampling, using adsorption, thermal desorption and following analysis on gas chromatography technique (GC), with FID, PID or MS detectors [6] [9] [10] [24] [25] [26] [27].

The introduction of portable measuring equipments made personal exposure assessment feasible; measurements of the BTEX compounds and selected inorganic compounds $\left(\mathrm{CO}, \mathrm{NO}_{\mathrm{x}}, \mathrm{O}_{3}\right.$ and $\left.\mathrm{SO}_{2}\right)$ were conducted using measuring techniques and devices installed in automatic monitoring stations.

In recent years, a great number of researchers began to use the portable emission measurement systems (PEMS) to study the emission characteristics of motor vehicles because of their ability to reflect emissions under real-world condi- 
tions [7] [28].

To analyse pollutants' concentration levels it is important to have information about weather, meteorological parameters (air temperature, humidity, atmospheric pressure, wind speed and direction, solar radiation and precipitation), but also detailed descriptions of sampling locations with the indications of potential emission sources.

The objective of this study is to evaluate the traffic-related concentrations of pollutants in urban air (BTEX, $\mathrm{NO}_{\mathrm{x}}, \mathrm{O}_{3}, \mathrm{SO}_{2}$ and $\mathrm{CO}, \mathrm{PM}_{10}, \mathrm{PM}_{2.5}$ ), with a mobile laboratory equipped with continuously monitoring devices (Table 1 ). The mobile laboratory was placed in three University campuses areas, visited daily by around 8000 students. The chosen places to be measured inside the University campuses were close to the University entrance. The ambient air was continuously drawn through a Teflon tube placed on the mobile laboratory rooftop at about $3 \mathrm{~m}$ up from the ground, and all the pollutants described in Table 1 were simultaneously measured. Data acquired quality is guaranteed by the periodic calibration of equipment.

The GC/FID has a capillary column, with a length of $60 \mathrm{~m}$, the separation being made by the temperature program: an isothermal of $50^{\circ} \mathrm{C}$ holds $3 \mathrm{~min}$, a heating rate of $8^{\circ} \mathrm{C} / \mathrm{min}$ to $180^{\circ} \mathrm{C} / \mathrm{min}$ holds $5 \mathrm{~min}$; the total time for analysis was $18 \mathrm{~min}$.

The concentration of particles $\mathrm{PM}_{2.5}$ was measured with a Portable Environmental Dust Monitor 11-E (manufactured by GRIMM) with a 5 min. time step [29] [30] [31]. Dust concentration $\mathrm{PM}_{10}$ was measured using a Verewa device, which is not able to measure simultaneously both $\mathrm{PM}_{10}$ and $\mathrm{PM}_{2.5}$.

The results can be processed and transmitted remotely using IOVIS software.

\section{Results and Discussions}

The present study indicates that the levels in the ambient air are directly related

Table 1. Characteristics of the mobile laboratory devices.

\begin{tabular}{|c|c|c|c|c|c|}
\hline Pollutant & Name & $\begin{array}{l}\text { Measurement } \\
\text { principle }\end{array}$ & $\begin{array}{l}\text { Measuring } \\
\text { range }\end{array}$ & $\begin{array}{l}\text { Detection } \\
\text { limit }\end{array}$ & $\begin{array}{c}\text { Accuracy } \\
\%\end{array}$ \\
\hline BTEX & GC 5000 AMA & GC/FID & $0-50 \mu \mathrm{g} / \mathrm{m}^{3}$ & $0.03 \mathrm{ppb}$ & $\pm 1.0 \%$ \\
\hline $\begin{array}{c}\mathrm{NO}_{\mathrm{x}} \\
\left(\mathrm{NO}+\mathrm{NO}_{2}\right)\end{array}$ & APNA 370 Horiba & Chemi-luminescence & $0-1.0 \mathrm{ppm}$ & $0.5 \mathrm{ppb}$ & $\pm 1.0 \%$ \\
\hline $\mathrm{O}_{3}$ & APOA 370 Horiba & Ultraviolet absorption & $0-1.0 \mathrm{ppm}$ & $0.5 \mathrm{ppb}$ & $\pm 1.0 \%$ \\
\hline $\mathrm{CO}$ & APMA 370 Horiba & $\begin{array}{l}\text { Non-dispersive } \\
\text { infrared absorption }\end{array}$ & $0-100$ ppm & $0.05 \mathrm{ppm}$ & $\pm 1.0 \%$ \\
\hline $\mathrm{SO}_{2}$ & APSA 370 Horiba & $\begin{array}{l}\text { Ultraviolet } \\
\text { fluorescence }\end{array}$ & $0-0.5 \mathrm{ppm}$ & $0.5 \mathrm{ppb}$ & $\pm 1.0 \%$ \\
\hline $\mathrm{PM}_{10}$ & F701-20 Verewa & $\begin{array}{l}\text { Beta radiation } \\
\text { adsorption }\end{array}$ & $0-10 \mathrm{mg} / \mathrm{m}^{3}$ & $0.001 \mathrm{mg} / \mathrm{m}^{3}$ & $\pm 2.0 \%$ \\
\hline $\mathrm{PM}_{2.5}$ & $\begin{array}{l}\text { Dust Monitor } \\
\text { 11-E Grimm }\end{array}$ & Laser radiation & $0.25-32 \mu \mathrm{m}$ & $0.1 \mu \mathrm{g} / \mathrm{m}^{3}$ & $\pm 2.0 \%$ \\
\hline
\end{tabular}


to the intensity and magnitude of the vehicles' number and type; the studied sites showed that their industrial surroundings and traffic compositions are different from each other (Figure 1). The concentrations are also indirectly related to dispersion, stability and wind speed. Thus the toxic air compounds can pose special threats in urban areas, because of the large number of students and people living near roads and facing heavy traffic.

The ratio of benzene to toluene $(\mathrm{B} / \mathrm{T})$ is commonly used to identify the BTEX emission sources. A ratio $\mathrm{B} / \mathrm{T}$ value of around 0.5 (wt./wt.) is found to be characteristic of vehicular emissions in many urban areas worldwide [31] [32].

However, when the source of emissions of organic compounds from the BTEX group is located at a close distance from the measuring/monitoring station (a "fresh" source of emissions), the value of the $\mathrm{m}, \mathrm{p} X / \mathrm{E}$ parameter is higher than 3.3 [34] [35]. Under ideal conditions, where the only source of emissions of BTEX compounds is vehicle traffic, the numerical values of the $\mathrm{B} \div \mathrm{T} \div$ $\mathrm{E} \div \mathrm{X}$ parameter is $3 \div 4 \div 1 \div 5$ and $\mathrm{B} \div \mathrm{E}<5$, and $\mathrm{T} \div \mathrm{E}<6$ [36] [37] .

In our study, the main source of pollution with BTEX is vehicular emission (Table 2).

In the diurnal variation of BTEX, during a sunny and rainy day (Figure 2), two peaks of BTEX concentration were observed in the morning and in the

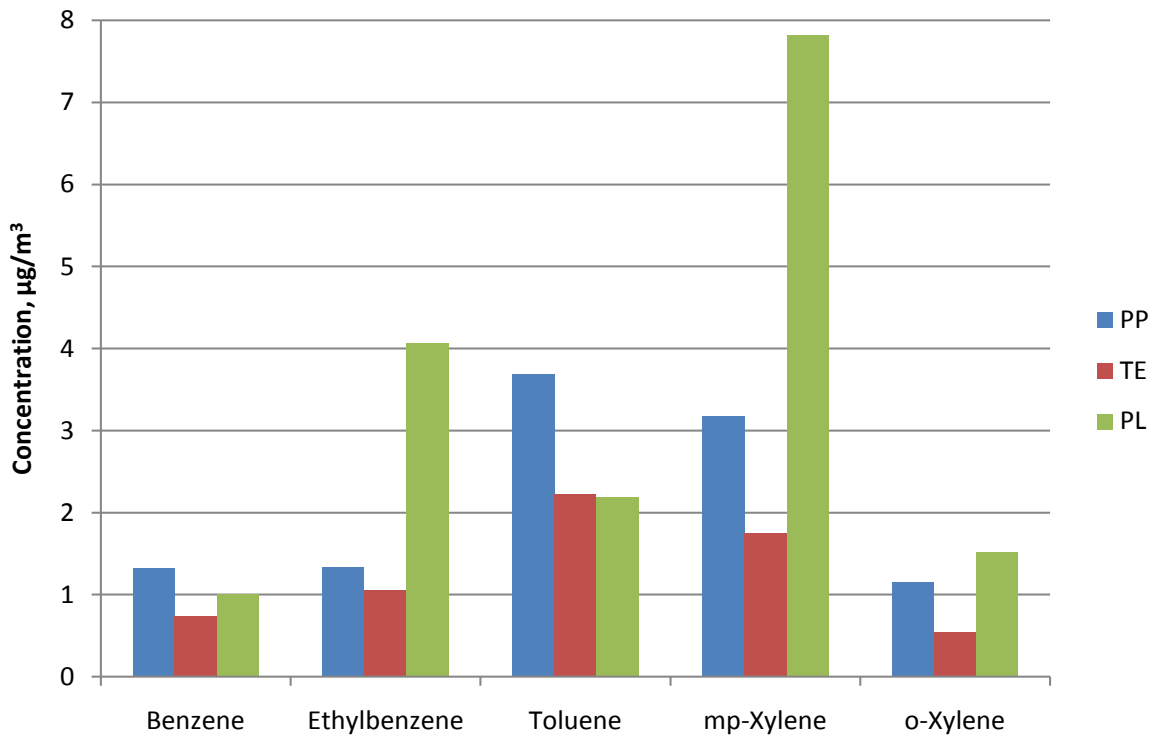

Figure 1. Comparison of mean concentration levels of BTEX from the three sites of campus.

Table 2. Ratio $\mathrm{B} / \mathrm{T}, \mathrm{B} / \mathrm{E}, \mathrm{T} / \mathrm{E}, \mathrm{m}, \mathrm{p} \mathrm{X} / \mathrm{E}$ and $\mathrm{B} \div \mathrm{T} \div \mathrm{E} \div \mathrm{X}$, in 3 sites of university campus from Bucharest.

\begin{tabular}{cccccc}
\hline Site $^{*}$ & $\mathrm{~B} / \mathrm{T}$ & $\mathrm{B} / \mathrm{E}$ & $\mathrm{T} / \mathrm{E}$ & $\mathrm{m}, \mathrm{p} \mathrm{X} / \mathrm{E}$ & $\mathrm{B} \div \mathrm{T} \div \mathrm{E} \div \mathrm{X}$ \\
\hline 1 & 0.3 & 1 & 3.4 & 3.3 & $1 \div 3.4 \div 1 \div 5.5$ \\
2 & 0.3 & 1 & 3.8 & 3.3 & $1 \div 3.7 \div 1 \div 4$ \\
3 & 0.5 & 0.2 & 0.5 & 3.4 & $0.2 \div 0.5 \div 1 \div 4$ \\
\hline
\end{tabular}

${ }^{*} \mathrm{PP}-1$; TE-2; PL-3. 


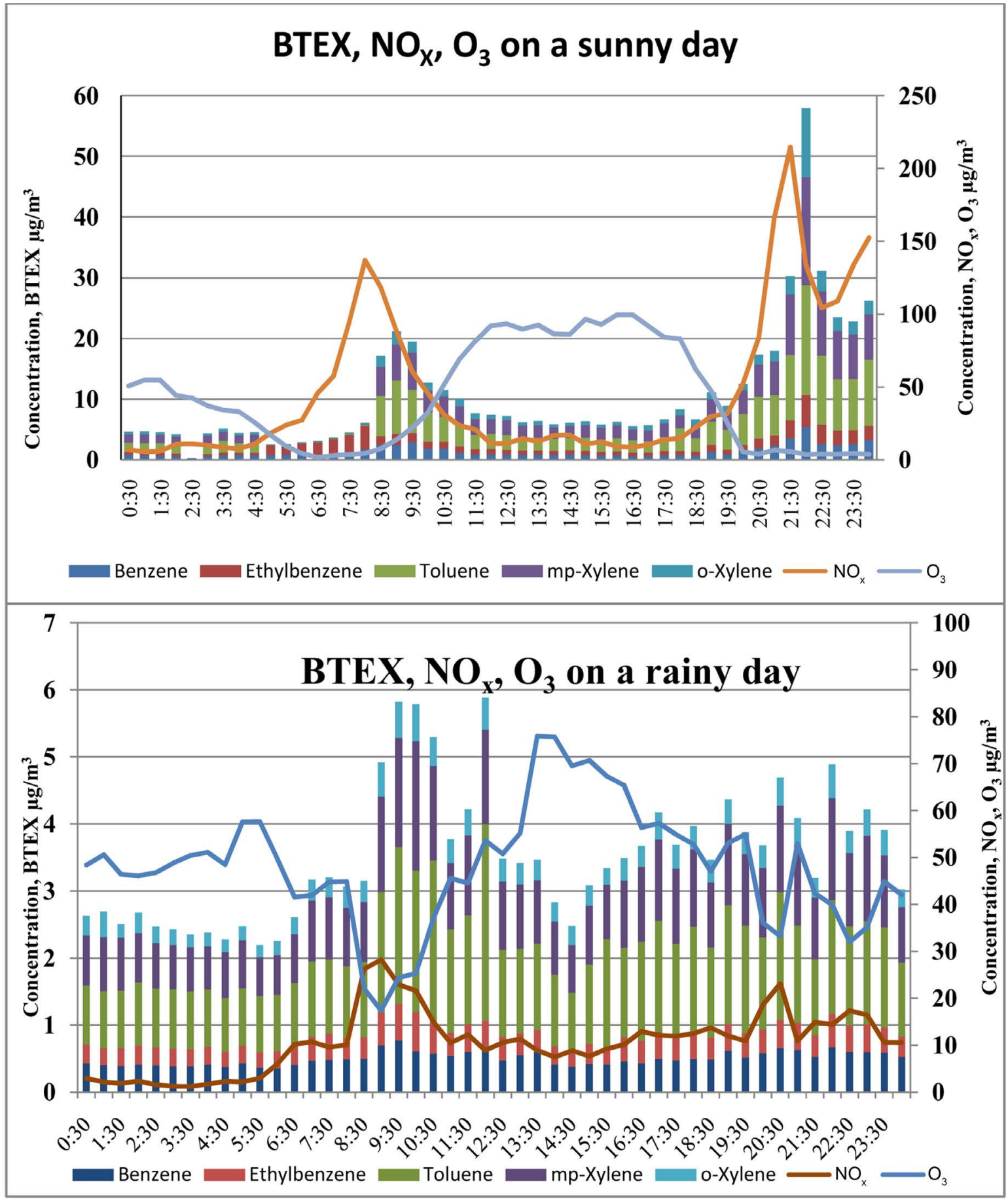

Figure 2. A typical sunny and rainy day, indicating levels of BTEX species, in the $1^{\text {st }}$ site (PP).

evening. The maximum concentration was recorded from 7:00 to 10:00 in the morning, and then decreased at around 15:00. Thereafter, the concentration increased again from 17:00 until 22:00, when the second BTEX peak occurred. This trend is very similar to the diurnal trends found in other urban areas [9] [38].

In the rainy days, the rain washes out the pollutants, thus the accumulation of BTEX is smaller than in the sunny days (Figure 2, Table 3). In the weekend day 
Table 3. Comparison of emissions, by Average \pm SD $(n=48)$, in a sunny day, a cold/ rainy day and a weekend day in the site $1^{\star}, \mu \mathrm{g} \cdot \mathrm{m}^{-3}$.

\begin{tabular}{cccc}
\hline Pollutant & Sunny day & Cold/rainy day & Weekend day \\
\hline Benzene & $1.32 \pm 1.01$ & $0.50 \pm 0.10$ & $0.56 \pm 0.26$ \\
Toluene & $3.68 \pm 3.73$ & $1.34 \pm 0.47$ & $1.56 \pm 0.97$ \\
Ethylbenzene & $1.33 \pm 1.04$ & $0.34 \pm 0.08$ & $0.47 \pm 0.23$ \\
m,p-Xylene & $3.18 \pm 3.34$ & $0.99 \pm 0.29$ & $1.35 \pm 0.72$ \\
o-Xylene & $1.15 \pm 1.70$ & $0.32 \pm 0.09$ & $0.43 \pm 0.21$ \\
$\mathrm{NO}$ & $32.0 \pm 49.8$ & $1.1 \pm 1.5$ & $1.6 \pm 1.8$ \\
$\mathrm{NO}$ & $41.2 \pm 26.4$ & $18.5 \pm 11.1$ & $18.1 \pm 15.8$ \\
$\mathrm{NO}_{\mathbf{x}}$ & $47.2 \pm 52.1$ & $10.6 \pm 6.6$ & $10.8 \pm 9.1$ \\
$\mathrm{O}_{3}$ & $42.9 \pm 35.8$ & $48.1 \pm 12.8$ & $61.3 \pm 24.6$ \\
$\mathrm{CO}^{*}$ & $0.5 \pm 0.4$ & $0.3 \pm 0.05$ & $0.3 \pm 0.1$ \\
$\mathrm{SO}_{2}$ & $1.3 \pm 1.0$ & $0.3 \pm 0.2$ & $0.8 \pm 0.7$ \\
$\mathrm{PM}_{10}$ & $84.4 \pm 43.1$ & $19.7 \pm 3.1$ & $33.3 \pm 10.4$ \\
$\mathrm{PM}_{2.5}$ & $23.5 \pm 5.4$ & $10.5 \pm 1.2$ & $13.5 \pm 7.4$ \\
\hline
\end{tabular}

${ }^{*} \mathrm{PP}-1 ;{ }^{* *} \mathrm{mg} / \mathrm{m}^{3}$.

the traffic is low so the pollution follows same trend (Table 3 ).

The non-polar (hydrophobic) compounds as BTEX are mechanically carried by rain to the ground where they either enter in the groundwater, with a piston effect, or volatilized and re-enter the atmospheric air [39].

In Table 4 benzene was $9 \%$ in the BTEX $_{\text {total }}$ in all three sites while o-xylene was found to be the most abundant species, with $43 \%$ of BTEX $_{\text {total }}$.

The maximum value of benzene, found in the studied sites, was $5.4 \pm 1.01$ $\mu \mathrm{g} / \mathrm{m}^{3}$ (Table 4). It is a matter of concern due to its carcinogenic effects, even in lower concentrations [41] [42]. In the Directive 50/EC, 2008 [43], on ambient air quality, the legislator recommends that the average annual concentration in the atmospheric air must not exceed $5 \mu \mathrm{g} / \mathrm{m}^{3}$ in the urbanized areas (Table 5). Benzene has a relatively long life span, low reactivity and is stable in the atmosphere.

The maximum value of toluene, ethylbenzene and xylenes $(\mathrm{m}, \mathrm{p}$ xylene and o-xylene) was found to be $18.07 \pm 3.73,8.86 \pm 2.68,(17.78 \pm 3.34$ and $11.38 \pm$ 1.7) respectively (Table 4 ), but that group are characterized by a very short life time in the atmospheric air in the urbanized area (in particular xylenes); these compounds undergo photochemical reactions more easily with the participation of strong oxidisers such as the hydroxyl radical. $\mathrm{OH}$, than benzene [33].

Table 4 shows high concentrations in $\mathrm{O}_{3}\left(123.56 \mu \mathrm{g} / \mathrm{m}^{3}\right)$, above the limit values $\left(120 \mu \mathrm{g} / \mathrm{m}^{3}\right.$, Table 5). High concentrations in $\mathrm{O}_{3}$ corresponds to low concentrations in $\mathrm{NO}_{\mathrm{x}}$ and xylene as can be observed in Figure 3, for a sunny day, due to photochemical reactions in the atmosphere, generating photochemical smog. During midday $(10.00-18.00)$ (Figure 3$)$, the solar radiation becomes strongest while BTEX and $\mathrm{NO}_{\mathrm{x}}$ decrease, which could be interpreted as a photochemical reaction, producing $\mathrm{O}_{3}$ [45]. There is a delay of 2 hours between the maximum solar radiation and the maximum produced $\mathrm{O}_{3}$ concentration linked 
Table 4. Measurement statistics in 3 sites of Campus from Bucharest, in $\mu \mathrm{g} / \mathrm{m}^{3}$.

\begin{tabular}{|c|c|c|c|c|c|}
\hline Pollutant & Site $^{*}$ & Mean & $\begin{array}{l}\text { Standard } \\
\text { deviation }\end{array}$ & Maximum & Minimum \\
\hline \multirow{3}{*}{ Benzene } & 1 & 1.32 & 1.01 & 5.40 & 0.08 \\
\hline & 2 & 0.74 & 0.36 & 1.73 & 0.35 \\
\hline & 3 & 0.84 & 0.25 & 1.45 & 0.51 \\
\hline \multirow{3}{*}{ Ethylbenzene } & 1 & 1.33 & 1.04 & 5.31 & 0.00 \\
\hline & 2 & 1.05 & 1.05 & 4.14 & 0.34 \\
\hline & 3 & 4.74 & 2.68 & 8.86 & 2.38 \\
\hline \multirow{3}{*}{ Toluene } & 1 & 3.69 & 3.73 & 18.07 & 0.05 \\
\hline & 2 & 2.22 & 1.39 & 5.92 & 0.12 \\
\hline & 3 & 1.17 & 0.93 & 3.04 & 0.05 \\
\hline \multirow{3}{*}{ mp-Xylene } & 1 & 3.18 & 3.34 & 17.78 & 0.00 \\
\hline & 2 & 1.74 & 0.99 & 4.26 & 0.05 \\
\hline & 3 & 5.33 & 4.12 & 9.82 & 0.10 \\
\hline \multirow{3}{*}{ o-Xylene } & 1 & 1.15 & 1.70 & 11.38 & 0.01 \\
\hline & 2 & 0.55 & 0.25 & 1.32 & 0.20 \\
\hline & 3 & 1.02 & 0.55 & 1.80 & 0.30 \\
\hline \multirow{3}{*}{$\mathrm{CO}^{* *}$} & 1 & 0.54 & 0.43 & 1.92 & 0.25 \\
\hline & 2 & 0.37 & 0.14 & 0.74 & 0.22 \\
\hline & 3 & 0.43 & 0.14 & 0.76 & 0.24 \\
\hline \multirow{3}{*}{ NO } & 1 & 32.06 & 49.78 & 207.80 & 0.00 \\
\hline & 2 & 18.09 & 30.81 & 126.30 & 0.09 \\
\hline & 3 & 3.77 & 2.90 & 10.81 & 0.00 \\
\hline \multirow{3}{*}{$\mathrm{NO}_{2}$} & 1 & 41.23 & 26.41 & 92.75 & 10.44 \\
\hline & 2 & 40.45 & 23.28 & 87.80 & 12.31 \\
\hline & 3 & 23.30 & 8.33 & 34.68 & 4.12 \\
\hline \multirow{3}{*}{$\mathrm{NO}_{\mathrm{x}}$} & 1 & 47.23 & 52.13 & 214.80 & 5.40 \\
\hline & 2 & 35.65 & 28.63 & 122.10 & 8.03 \\
\hline & 3 & 15.21 & 6.35 & 25.73 & 2.07 \\
\hline \multirow{3}{*}{$\mathrm{O}_{3}$} & 1 & 54.34 & 49.06 & 121.66 & 1.63 \\
\hline & 2 & 55.12 & 49.23 & 123.56 & 0.38 \\
\hline & 3 & 28.42 & 10.62 & 47.07 & 5.77 \\
\hline \multirow{3}{*}{$\mathrm{SO}_{2}$} & 1 & 1.28 & 1.06 & 5.07 & 0.00 \\
\hline & 2 & 2.86 & 1.52 & 6.45 & 0.86 \\
\hline & 3 & 2.34 & 2.15 & 11.30 & 0.81 \\
\hline \multirow{3}{*}{$\mathrm{PM}_{10}$} & 1 & 58.49 & 27.10 & 164.06 & 29.36 \\
\hline & 2 & 29.12 & 10.41 & 46.00 & 15.00 \\
\hline & 3 & 16.17 & 3.49 & 22.00 & 10.00 \\
\hline $\mathrm{PM}_{2.5}$ & 1 & 18.28 & 3.68 & 29.26 & 12.08 \\
\hline
\end{tabular}

${ }^{*} \mathrm{PP}-1 ; \mathrm{TE}-2 ; \mathrm{PL}-3 ;{ }^{* *} \mu \mathrm{g} / \mathrm{m}^{3}$. 
Table 5. Limit values and alert thresholds, directive 50/2008/EC (ambient air quality) [43].

\begin{tabular}{rccccc}
\hline \multirow{2}{*}{ Pollutant } & \multicolumn{3}{c}{ Limit values } & \multirow{2}{*}{$\begin{array}{c}\text { Alert } \\
\text { thresholds }\end{array}$} \\
\cline { 2 - 4 } & 1 hour & 8 hour & 1 day & Annual & 500 \\
$\mathrm{SO}_{2}, \mu \mathrm{g} / \mathrm{m}^{3}$ & 350 & & 125 & & 400 \\
$\mathrm{NO}_{2}, \mu \mathrm{g} / \mathrm{m}^{3}$ & 200 & & & 40 & \\
$\mathrm{CO}, \mathrm{mg} / \mathrm{m}^{3}$ & & 10 & & 240 \\
$\mathrm{O}_{3}, \mu \mathrm{g} / \mathrm{m}^{3}$ & 120 & & 5 & \\
$\mathrm{Benzene}, \mu \mathrm{g} / \mathrm{m}^{3}$ & & & & & \\
$\mathrm{PM}_{10}, \mu \mathrm{g} / \mathrm{m}^{3}$ & & 50 & 40 & \\
$\mathrm{PM}_{2.5}, \mu \mathrm{g} / \mathrm{m}^{3}$ & & & 24 & \\
\hline
\end{tabular}

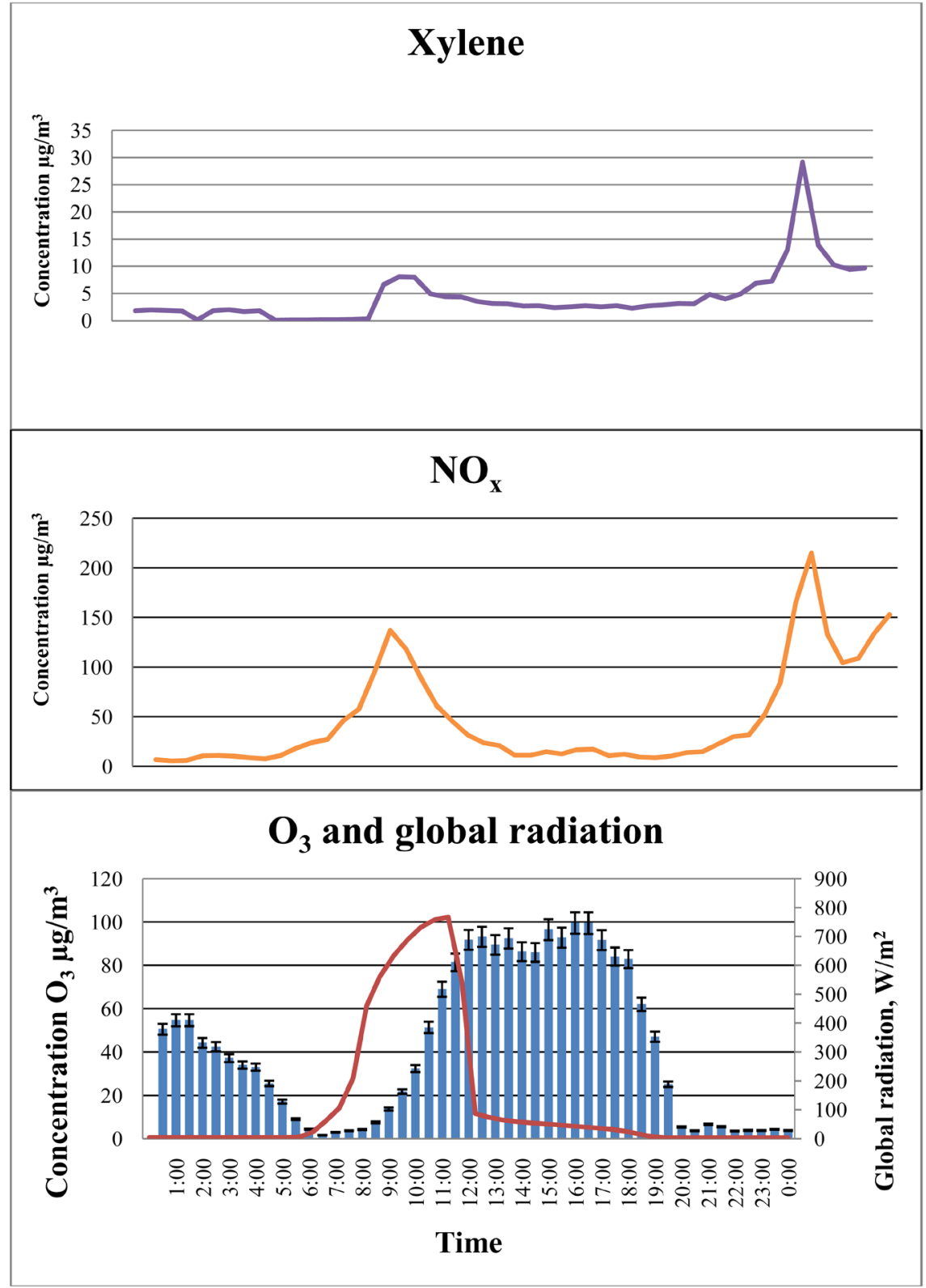

Figure 3. Diurnal variations of total xylene, $\mathrm{NO}_{\mathrm{x}}$, global radiation and $\mathrm{O}_{3}$ from a typical sunny day. 
to the photochemical reaction conditions.

Toluene and xylenes have a lower toxicity level than benzene. When exposed to photochemical reactions in the atmosphere they also can react to form new toxic compounds (peroxybenzoyl nitrates, carbonyl compounds etc.) which can result in adverse health effects [44].

The BTEX present in air can affect the environment in two ways, directly \& indirectly. After BTEX are discharged into the atmosphere, they cause not only pollution problems on a local scale, but also play an important role on a regional scale, having effects such as acid rain, photochemical ozone formation introduced by the reaction with $\mathrm{OH}$ radicals in the troposphere, in the presence of nitrogen oxides and sunlight and increased risk of cancer [40].

$\mathrm{CO}$ results from an incomplete combustion of diesel fuel or gasoline in traffic engines; high concentrations of $\mathrm{CO}$, generally, result from poor vehicle maintenance and an insufficient use of vehicle emission control systems [2]. In our study the concentration in $\mathrm{CO}$ was lower than the limit value.

Vehicles can also be a source of $\mathrm{SO}_{2}$ emissions. However, the condition must be met that the fuel used in vehicles is contaminated with sulphur compounds. Interpretation of data summarized in Table 4 shows that sulphur dioxide concentration in the atmospheric air in the 3 sites is very low. This can result from the fact that high-quality liquid fuels are used in vehicles, which are virtually free from sulphur compounds.

The seasonal variations of meteorological conditions may influence the dispersion, photochemical reactions, and emissions of air pollutants. The wind speed, for example, was very low $(1.4 \pm 0.7 \mathrm{~m} / \mathrm{s} ; 1.6 \pm 1.4 \mathrm{~m} / \mathrm{s}$ and $1.6 \pm 1.1 \mathrm{~m} / \mathrm{s}$ in the three sites), implying the dominance of local air masses at the monitoring site.

Particulate matters such as $\mathrm{PM}_{10}$ and $\mathrm{PM}_{2.5}$ are, in a large part, carried by rain into the soil. The polar compounds (hydrophilic, $\mathrm{NO}_{\mathrm{x}}, \mathrm{SO}_{2}$ ) dissolve in rainwater and are absorbed into the soil (increasing soil acidity) or evaporates to the clouds (leading to acid rain). Figure 4 shows that measured $\mathrm{PM}_{10}$ concentrations in site 1 during the sunny days are above the one day limit values according to Directive 50/2008/EC for ambient air quality (Table 5).

In our study, BTEX compounds were removed by the rain between $62 \%$ $75 \%, \mathrm{NO}_{\mathrm{x}}$ and $\mathrm{SO}_{2} 80 \%$ and $77 \%$ respectively. Concerning the particulate matters, they were washed out in a percentage of $68 \%-85 \%$ for $\mathrm{PM}_{10}$ and $42 \%-69 \%$ for $\mathrm{PM}_{2.5}$ (Figure 4).

\section{Conclusions}

The interpretation of the results, in the monitoring study, obtained for the three sites of the University campuses, related to the atmospheric air pollution produced by urban traffic, showed that:

- in a sunny day with normal traffic we found that the maximum value 5.4 $\mu \mathrm{g} / \mathrm{m}^{3}$ for benzene, a known human carcinogen, for $30 \mathrm{~min}$., exceeding the annual limit value of $5 \mu \mathrm{g} / \mathrm{m}^{3}$; high concentrations in $\mathrm{O}_{3}$ were determined for 


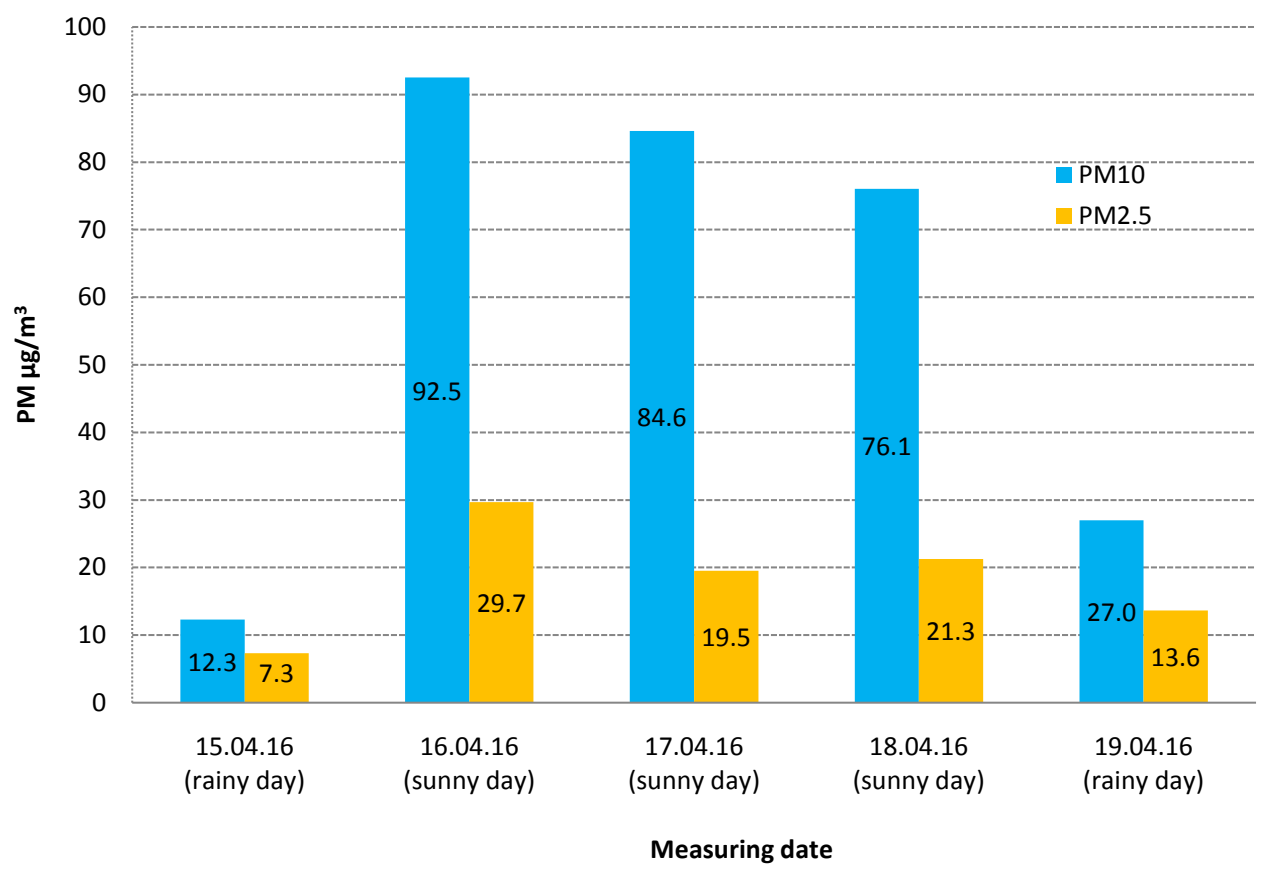

Figure 4. Comparison of $\mathrm{PM}_{10}$ and $\mathrm{PM}_{2.5}$ in a sunny and rainy day in the site 1 (PP).

a 7 hours period $\left(121.66 \pm 7.02,123.56 \pm 4.89 \mu \mathrm{g} / \mathrm{m}^{3}\right)$ being above the limit value $\left(120 \mu \mathrm{g} / \mathrm{m}^{3}\right)$. The maximum of solar radiation, with corresponding low concentrations in $\mathrm{NO}_{\mathrm{x}}$ and xylene, involves the formation of photochemical smog;

- in a rainy day, the rain washed out $62 \%-75 \%$ of BTEX, $80 \% \mathrm{NO}_{\mathrm{x}}, 77 \% \mathrm{SO}_{2}$ and $68 \% \mathrm{PM}_{10}, 42 \% \mathrm{PM}_{2.5}$.

The study of Ballesta [46] showed that background ambient air quality defines a baseline for exposure of the population upon which emissions related to activities or locations are superimposed. Daily average values of human exposure, for a non-smoking population, were approximately 1.5 times the level of urban background.

The average background, from benzene, in our 3 sites, was $0.97 \mu \mathrm{g} / \mathrm{m}^{3}$ and the exposure for students was $1.46 \mu \mathrm{g} / \mathrm{m}^{3}$.

The U.S. EPA (2005) [47] cancer risk analysis estimates that an individual exposed to benzene levels between 1.3 and $4.5 \mu \mathrm{g} / \mathrm{m}^{3}$ faces an increased risk to $1 / 100,000$, which corresponds to our monitored case.

\section{References}

[1] Paralovo, S.L., Borillo, G.C., Barbosa, C.G.G., et al. (2016) Observations of Atmospheric Monoaromatic Hydrocarbons at Urban, Semi-Urban and Forest Environments in the Amazon Region. Atmospheric Environment, 128, 175-184.

https://doi.org/10.1016/j.atmosenv.2015.12.053

[2] Han, X. and Naeher, L.P. (2006) A Review of Traffic-Related Air Pollution expoSure Assessment Studies in the Developing World. Environment International, 32, 106120. https://doi.org/10.1016/j.envint.2005.05.020

[3] Atkinson, R. (2000) Atmospheric Chemistry of VOCs and $\mathrm{NO}_{\mathrm{x}}$. Atmospheric Environment, 34, 2063-2101. https://doi.org/10.1016/S1352-2310(99)00460-4 
[4] Popescu, M. and Popescu, M. (2000) Ecologie Aplicata. Ed. MatrixRom., Bucuresti. 148-156.

[5] Ling, Z. and Guo, H. (2014) Contribution of VOC Sources to Photochemical Ozone Formation and Its Control Policy Implication in Hong Kong. Environmental Science \& Policy, 38, 180-191. https://doi.org/10.1016/j.envsci.2013.12.004

[6] Lyu, X.P., Chen, N., Guo, H., Zhang, W.H., Wang, N., Wang, Y. and Liu, M. (2016) Ambient Volatile Organic Compounds and Their Effect on Ozone Production in Wuhan, Central China. Science of the Total Environment, 541, 200-209. https://doi.org/10.1016/j.scitotenv.2015.09.093

[7] Cao, X., Yao, Z., Shen, X., Ye, Y. and Jiang, X. (2016) On-Road Emission Characteristics of VOCs from Light-Duty Gasoline Vehicles in Beijing, China. Atmospheric Environment, 124, 146-155.

[8] Lee, S.C., Chiu, M.Y., Ho, K.F., Zou, S.C. and Wang, X.M. (2002) Volatile Organic Compounds (VOCs) in Urban Atmosphere of Hong Kong. Chemosphere, 48, 375382. https://doi.org/10.1016/S0045-6535(02)00040-1

[9] Song, Y., Dai, W., Shao, M., Liu, Y., Lu, S.H., Kuster, W. and Goldan, P. (2008) Comparison of Receptor Models for Source Apportionment of Volatile Organic Compounds in Beijing, China. Environmental Pollution, 156, 174-183. https://doi.org/10.1016/j.envpol.2007.12.014

[10] Wu, F., Yu, Y., Sun, J., Zhang, J., Wang, J., Tang, G. and Wang, Y. (2016) Characteristics, Source Apportionment and Reactivity of Ambient Volatile Organic Compounds at Dinghu Mountain in Guangdong Province, China. Science of the Total Environment, 548-549, 347-359. https://doi.org/10.1016/j.scitotenv.2015.11.069

[11] Mitra, S. and Roy, P. (2011) BTEX: A Serious Ground-Water Contaminant. Research Journal of Environmental Sciences, 5, 394-398. https://doi.org/10.3923/rjes.2011.394.398

[12] Tiwari, V., Hanai, Y. and Masunaga, S. (2010) Ambient Levels of Volatile Organic Compounds in the Vicinity of Petrochemical Industrial Area of Yokohama, Japan. Air Quality, Atmosphere and Health, 3, 65-75. https://doi.org/10.1007/s11869-009-0052-0

[13] U.S. Environmental Protection Agency (1993). http://www.epa.gov/otaq/regs/toxics/airtoxlb.pdf

[14] Stominska, M., Konieczka, P. and Namiesnik, J. (2014) The Fate of BTEX Compounds in Ambient Air. Critical Reviews in Environmental Science and Technology, 44, 455-472. https://doi.org/10.1080/10643389.2012.728808

[15] Kanjanasiranont, N., Prueksasit, T., Morknoy, D., Tunsaringkarn, T., et al. (2016) Determination of Ambient Air Concentrations and Personal Exposure Risk Levels of Outdoor Workers to Carbonyl Compounds and BTEX in the Inner City of Bangkok, Thailand. Atmospheric Pollution Research, 7, 268-277.

[16] Snyder, R. (2012) Leukemia and Benzene. International Journal of Environmental Research and Public Health, 9, 2875-2893. https://doi.org/10.3390/ijerph9082875

[17] IARC International Agency for Research on Cancer (1989) Working Group on the Evaluation of Carcinogenic Risks to Humans. Monographs on the Evaluation of Carcinogenic Risks to Humans, 45, 1-322.

[18] Fustinoni, S., Bollati, V. and Bertazzi, P.A. (2013) Modificazioni epigenetiche nell'esposizione a basse dosi di benzene. Giornale italiano di medicina del lavoro ed ergonomia, 35, 263-267.

[19] Bais, F.Y., Woodruff, T.J. and Spear, R.C. (1991) Mechanism of Benzene Carcinogenesis: Application of a Physiological Model of Benzene Pharmacokinetics and 
Metabolism. Toxicology Letters, 56, 283-298.

[20] Wróbel, A., Rokita, E. and Maenhaut, W. (2000) Transport of Traffic-Related Aerosols in Urban Areas. Science of the Total Environment, 257, 199-211.

[21] Popescu, R.S., Blondeau, P., Jouandon, E., Costes, J.C. and Fanlo, J.L. (2013) Elemental Modeling of Adsorption Filter Efficiency for Indoor Air Quality Applications. Building and Environment, 66, 11-22.

[22] Safari, V., Haghighat, F., Lee, C., Blondeau, P., Popescu, R.S. and Lakdawala, N. (2013) Asystematic Approach for Evaluation of Gas-Phase Filter Model. HVAC \& R Research, 19, 705-714.

[23] Demirel, G., Ozden, O., Dogeroglu, T. and Gaga, E.O. (2014) Personal Exposure of Primary School Children to BTEX, $\mathrm{NO}_{2}$ and Ozone in Eskisehir, Turkey: Relationship with Indoor/Outdoor Concentrations and Risk Assessment. Science of the Total Environment, 473-474, 537-548.

[24] Popescu, M., Popescu, R. and Stratula, C. (2006) Treatment Physic-Chemical Methods for Industrial and Atmospherical Pollutants. Academiei Romane, Bucharest, 246-249.

[25] Moolla, R., Curtis, C.J. and Knight, J. (2015) Assessment of Occupational Exposure to BTEX Compounds at a Bus Diesel-Refueling Bay: A Case Study in Johannesburg, South Africa. Science of the Total Environment, 537, 51-57.

[26] Marć, M., Bielawska, M., Simeonov, V., Namieśnik, J. and Zabiegała, B. (2016) The Effect of Anthropogenic Activity on BTEX, $\mathrm{NO}_{2}, \mathrm{SO}_{2}$ and $\mathrm{CO}$ Concentrations in Urban Air of the Spa City of Sopot and Medium-Industrialized City of Tczew Located in North Poland. Environmental Research, 147, 513-524.

[27] Kumar, A. and Tyagi, S.K. (2006) Benzene and Toluene Profiles in Air of Delhi as Determined by Active Sampling and GC Analysis. Journal of Scientific \& Industrial Research, 65, 252-257.

[28] Yao, Z., Wang, Q., He, K., Huo, H., Ma, Y. and Zhang, Q. (2007) Characteristics of Real World Vehicular Emissions in Chinese Cities. Journal of the Air \& Waste Management Association, 57, 1379-1386. https://doi.org/10.3155/1047-3289.57.11.1379

[29] Olea Popescu, L., Limam, K. and Colda, I. (2009) A Numerical Research on Solid Particles Penetration through Buildings Envelope Cracks. Proceedings of International Symposium on Convective Heat and Mass Transfer in Sustainable Energy, 948-956. https://doi.org/10.1615/ICHMT.2009.CONV.780

[30] Popescu, L. and Limam, K. (2012) Particle Penetration Research through Buildings Cracks. HVAC \& R Research, 18, 312-322.

[31] Lindner, G.A., Limam, K., Popescu, L. and Benhamou, B. (2015) Evaluating the Performance of Two Eddy-Viscosity Turbulence Models to Predict Airflow and Local Mean Age of Air. International Journal of Mechanics and Energy, 3, 67-76.

[32] Brocco, D., Fratarcangeli, R., Lepore, L., Petricca, M. and Ventrone, I. (1997) Determination of Aromatic Hydrocarbons in Urban Air of Rome. Atmospheric Environment, 31, 557-566.

[33] Monod, A., Sive, B.C., Avino, P., Chen, T., Blake, D.R. and Sherwood Rowland, F. (2001) Monoaromatic Compounds in Ambient Air of Various Cities: A Focus on Correlations between the Xylenes and Ethylbenzene. Atmospheric Environment, 35, 135-149.

[34] Hsieh, L.T., Wang, Y.F., Yang, H.H. and Mi, H.H. (2011) Measurements and Correlations of MTBE and BETX in Traffic Tunnels. Aerosol and Air Quality Research, 11, 763-775. 
[35] Cerón-Bretón, J.G., Cerón-Bretón, R.M., Kahl, J.D.W., Ramírez-Lara, E., Guarnaccia, C., Aguilar-Ucán, C.A., Montalvo-Romero, C., Anguebes-Franseschi, F. and LópezChuken, U. (2015) Diurnal and Seasonal Variation of BTEX in the Air of Monterrey, Mexico: Preliminary Study of Sources and Photochemical Ozone Pollution. Air Quality, Atmosphere and Health, 8, 469-482. https://doi.org/10.1007/s11869-014-0296-1

[36] Wang, X., Sheng, G., Fu, J., Chan, C., Lee, S.C., Chan, L.Y. and Wang, Z. (2002) Urban Road Side Aromatic Hydrocarbons in Three Cities of the Pearl River Delta, People's Republic of China. Atmospheric Environment, 36, 5141-5148.

[37] Khoder, M. (2007) Ambient Levels of Volatile Organic Compounds in the Atmosphere of Greater Cairo. Atmospheric Environment, 41, 554-566.

[38] Ho, K.F., Lee, S.C., Guo, H. and Tsai, W.Y. (2004) Seasonal and Diurnal Variations of Volatile Organic Compounds (VOCs) in the Atmosphere of Hong Kong. Science of the Total Environment, 322, 155-166.

[39] Carré, J., Popescu, M. and Blanchard, J.M. (1999) Extraction et analyse de composés organiques volatils (solvants industriels, HAP) dans des matrices solides (sols, roches poreuses, charbon actif). Science and Technology of Environemental Protection, 6, 1.

[40] Finlayson-Pitts, B.J. and Pitts, J.N. (1986) Atmospheric Chemistry: Fundamentals and Experimental Techniques. Wiley Interscience, New York.

[41] Duarte-Davidson, R., Courage, C., Rushton, L. and Levy, L. (2001) Benzene in the Environment: An Assessment of the Potential Risks to the Health of the Population. Occupational and Environmental Medicine, 58, 2-13. https://doi.org/10.1136/oem.58.1.2

[42] World Health Organisation (2012) IARC: Diesel Engine Exhaust Carcinogenic. IARC Monogr. Eval. Carcinog. Risks Hum. 105, Press Release 213, Lyon. http://www.iarc.fr/en/media-centre/iarcnews/2012/mono105-info.php

[43] Directive 2008/50/EC. http://eur-lex.europa.eu/legal-content/EN/TXT/?uri=CELEX:32008L0050

[44] Seinfeld, J.H. and Pandis, S.N. (2012) Atmospheric Chemistry and Physics: From Air Pollution to Climate Change. John Wiley \& Sons, Hoboken.

[45] Warneke, C., de Gouw, J.A., Goldan, P.D., Kuster, W.C., Williams, E.J., Lerner, B.M., et al. (2004) Comparison of Daytime and Night-Time Oxidation of Biogenic and Anthropogenic $\mathrm{VOC}_{\mathrm{s}}$ along the New England Coast in Summer during New England Air Quality Study 2002. Journal of Geophysical Research, 109, 1030910309. https://doi.org/10.1029/2003JD004424

[46] Ballesta, P.P., Field, R.A., Connolly, R., Cao, N., Caracena, A.B. and De Saeger, E. (2006) Population Exposure to Benzene: One Day Cross-Sections in Six European Cities. Atmospheric Environment, 40, 3355-3366.

[47] U.S. EPA (2005) Guidelines for Carcinogenic Risk Assessment. Risk Assessment Forum, EPA/630/P-03/001F, March 2005. 
Submit or recommend next manuscript to SCIRP and we will provide best service for you:

Accepting pre-submission inquiries through Email, Facebook, LinkedIn, Twitter, etc. A wide selection of journals (inclusive of 9 subjects, more than 200 journals)

Providing 24-hour high-quality service

User-friendly online submission system

Fair and swift peer-review system

Efficient typesetting and proofreading procedure

Display of the result of downloads and visits, as well as the number of cited articles Maximum dissemination of your research work

Submit your manuscript at: http://papersubmission.scirp.org/

Or contact jep@scirp.org 